\title{
ARTICLE
}

\section{The 2011 Eastern Japan Great Earthquake Disaster: Overview and Comments}

\author{
Okada Norio ${ }^{1}$, Tao $\mathrm{Ye}^{2, *}$, Yoshio Kajitani ${ }^{1}$, Peijun $\mathrm{Shi}^{2}$, and Hirokazu Tatano ${ }^{1}$ \\ ${ }^{1}$ Disaster Prevention Research Institute, Kyoto University, Kyoto 611-011, Japan \\ ${ }^{2}$ State Key Laboratory of Earth Surface Processes and Resource Ecology, Beijing Normal University, Beijing 100875, China
}

\begin{abstract}
This article briefly reviews the causes and impacts of the massive eastern Japan earthquake and tsunami of 11 March 2011, and comments on the response measures taken by Japan to cope with this devastating disaster. Mass losses occurred mostly because the intensity of the quake and the induced tsunami exceeded local coping capacity. Particularly, the nuclear power plant crisis triggered by the tsunami significantly increased the short- and long-term impacts of the disaster. While the coping capacity Japanese society built after the 1995 Hanshin-Awaji great earthquake tremendously mitigated the damages, there is room for improvement despite Japan's great efforts in this disaster. Investigating the tsunami preparedness of the coastal nuclear power plants is an issue of paramount importance. In response to future large-scale disasters, there is an urgent need for a highly collaborative framework based on which all available resources could be mobilized; a mutual assistance and rescue system against catastrophes among regions and countries on the basis of international humanitarian aid; and further in-depth research on the multi-hazard and disaster-chain phenomenon in large-scale disasters and corresponding governance approaches.
\end{abstract}

Keywords 2011 Eastern Japan Earthquake, earthquaketsunami disaster chain, Fukushima nuclear crisis, impact and response

\section{Introduction}

On 11 March 2011, a magnitude 9.0 earthquake occurred in the international waters of the western Pacific and induced a huge tsunami. These natural disasters hit the northeastern part of Japan and caused heavy casualties, enormous property losses, and a severe nuclear crisis with regional and global long-term impact. On April 1, the Japanese government officially named the disaster "The 2011 Tōhoku Earthquake and Tsunami” (東日本大震災, Higashi Nihon Daishinsai, literally “Eastern Japan Great Earthquake Disaster").

\footnotetext{
* Corresponding author. E-mail: yetao@bnu.edu.cn
}

\section{Characteristics of the 2011 Japan Earthquake and Tsunami}

The main earthquake disaster hit Japan at 14:46 Tokyo time on 11 March 2011 . The epicenter was estimated at $38.322^{\circ} \mathrm{N}$ and $142.369^{\circ} \mathrm{E}$ (Figure 1), merely $77 \mathrm{~km}$ (47.9 miles) off the eastern coast of Japan's Honshu island, $129 \mathrm{~km}$ from Sendai, $177 \mathrm{~km}$ from Fukushima, and $373 \mathrm{~km}$ from Tokyo. The hypocenter was at an underwater depth of $32 \mathrm{~km}$ (19.9 miles).

According to the Japan Meteorological Agency (2011), the magnitude estimate of this quake was initially 7.9 , then revised to $8.4,8.8,8.9$, back to 8.8 , and finally set at 9.0 . The data released by the United States Geological Survey was 8.8, but revised to 8.9 the same day. On March 14, it was finally set at 9.0. This 9.0 magnitude earthquake is the third highest ever recorded in the world, after the 9.5 magnitude quake that hit Chile in 1960 and the 9.2 magnitude quake that hit Alaska in 1964.

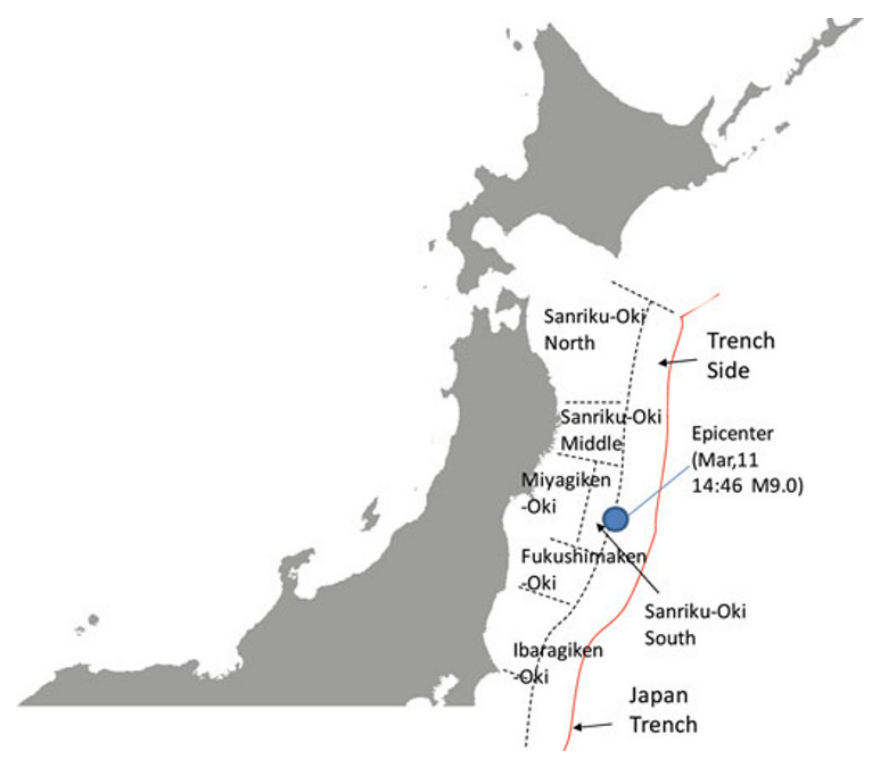

Figure 1. Epicenter of the 2011 Great Earthquake in Japan Tokai and the hypocentral regions classified by the Earthquake Survey Committee, Japan

Source: Earthquake Survey Committee, Japan 2011 
A number of foreshocks and aftershocks occurred before and after the main quake. Several thousand quakes were recorded by April 11. Relatively severe foreshocks and aftershocks included a magnitude 7.2 foreshock on March 9, and magnitude 7.0, 7.4, and 7.2 aftershocks at 15:06 Japan Standard Time (JST), 15:15 JST, and 15:26 JST on March 11. On April 7 and 11, magnitude 7.4 (revised to 7.1) and 7.1 aftershocks occurred.

The main quake triggered a massive, destructive tsunami (Figure 2). It reached the eastern coast of Honshu, Japan within a couple of minutes after the quake, and spilled into the interior to a maximum distance of $10 \mathrm{~km}$. It was estimated that the tsunami wave was up to $38 \mathrm{~m}$ high (Kyodo News 2011), while field observation suggested that the record was $24 \mathrm{~m}$, according to the figure released by the Port and Airport Research Institute (2011) on March 23. Based on the analysis of the Japan Meteorological Research Institute (JMRI 2011), the wave source zone of the tsunami covered about $550 \mathrm{~km}$ from north to south and about $200 \mathrm{~km}$ from east to west, setting a record for the most extensive wave source zone around the Japan Sea.

The tsunami caused by the quake affected almost the whole Pacific coast, and over 20 countries on both sides of the Pacific issued tsunami warnings, including Japan, Russia, the Philippines, Indonesia, Australia, New Zealand, Papua New Guinea, Fiji, Mexico, Guatemala, El Salvador, Costa Rica, Nicaragua, Honduras, Panama, Columbia, Ecuador, Peru, Chile, and the United States.

The quake released surface energy of $1.9 \pm 0.5 \times 10^{17} \mathrm{~J}$ (USGS Earthquake Hazards Program 2011a), two times that of the Indonesia tsunami in 2004. The total energy released, including shaking and the tsunami, amounted to $3.9 \times 10^{22} \mathrm{~J}$ (USGS Earthquake Hazards Program 2011b), slightly lower than that of the Indonesia tsunami, equivalent to $9.32 \times 10^{12} \mathrm{t}$ of TNT or about 600 million times that of the Hiroshima atom bomb.
Analysis of the USGS (USGS Earthquake Hazards Program 2011b) showed that this earthquake was triggered as the Pacific Plate slipped beneath Japan, while moving towards the Eurasian Plate to the west. Before this disaster, the Pacific Plate moved a few centimeters west away from the North American Plate every year, which led to this large earthquake as plate movement released energy.

The March 11 earthquake was induced by at least four different hypocenters slipping in a short period (see Figure 1). Based on the aftershock records, these hypocenters include not only Sanriku-Oki and Miyagiken-Oki, the two hypocenters considered most likely to have slipped, but also Fukushimaken-Oki and Ibaragiken-Oki. Such large-scale, interrelated earthquakes had not been envisioned by many earthquake experts.

\section{Impacts of the 2011 Eastern Japan Great Earthquake Disaster}

\subsection{Geophysical Impact}

The violent shock resulting from the seismic intensity moved the Honshu island of Japan about $3.6 \mathrm{~m}$ to the east, shifted the earth's axis by $25 \mathrm{~cm}$, and accelerated the planet's rotation by 1.8 microseconds (Chai 2011; CBS News 2011). A total of $400 \mathrm{~km}$ of Japan's east coast has subsided about $0.6 \mathrm{~m}$ because of the quake (Chang 2011). Ojika-hantou of Miyagi-ken, located northwest of the epicenter, has moved about $5.3 \mathrm{~m}$ southeast towards the epicenter, with a simultaneous subsidence of about $1.2 \mathrm{~m}$. The World Meteorological Organization has warned the Japanese government of potentially more severe flood risk in the northeastern part of Japan in the future (Xinhuanet 2011).

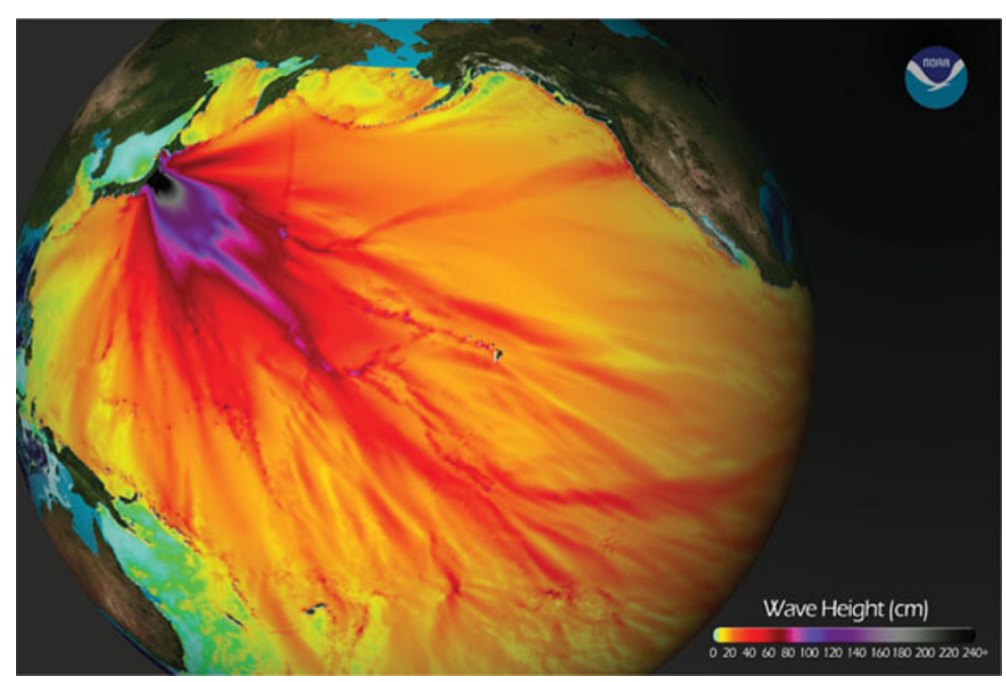

Figure 2. Tsunami caused by the 2011 Eastern Japan Great Earthquake Source: NOAA 2011. 


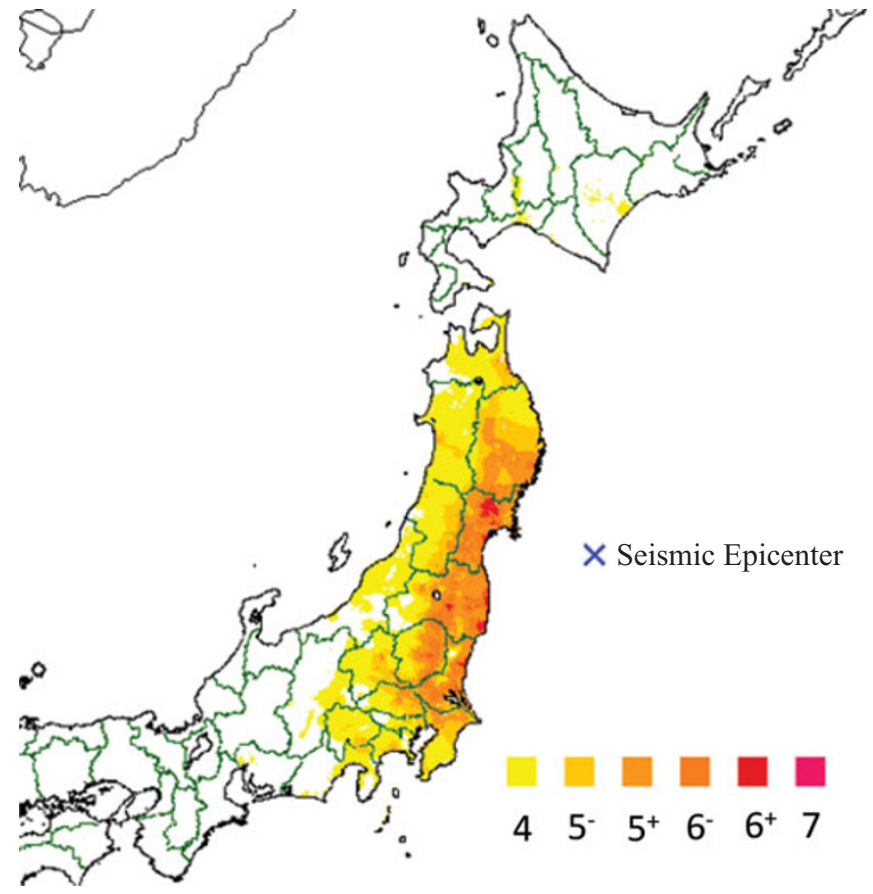

Figure 3. Estimated seismic intensity from observation stations right after 14:46 on 11 March 2011

Source: Japan Meteorological Agency 2011.

\subsection{Humanitarian Impact}

The influence exerted by the seismic event itself was not so striking. Only one prefecture was impacted with a seismic intensity of VII, and eight prefectures were impacted with a seismic intensity greater than VI (Figure 3). But the losses incurred by the earthquake and tsunami together were extremely severe. According to statistical data from the Japan National Police Agency (Table 1), by April 13, there were in total 13,392 people dead nationwide and 15,133 missing. More than 335,000 refugees in northeast Japan are lacking in food, water, shelters, medical care, and even the necessary means to conduct funerals for the deceased. ${ }^{i}$

\subsection{Impact on Buildings}

Up to April 3, there were 190,000 buildings damaged, among which 45,700 were totally destroyed. The damaged buildings in Miyagi, Iwate, and Fukushima were 29,500, 12,500, and 2400, respectively (NHK World 2011). By April 13, the number was further verified by the Japan Police Agency and increased (Table 1). About 250 million tons of rubble and debris were produced in Japan because of the earthquake and tsunami disaster.

\subsection{Impact on Key Infrastructures}

Several nuclear power plants and thermal power plants were heavily damaged in this disaster and details will be elaborated later in this article. The power supply of the Tokyo Electric
Power Company (TEPCO) was reduced by $21 \mathrm{GW}$, causing outages for 4.4 million families in eastern Japan (Japan Times 2011; The Nikkei 2011). From March 14 to March 29, TEPCO implemented rolling blackouts in most areas of Tokyo. Meanwhile, with the support of Tokyo residents' power-saving activities and temporary supply from steel manufacturers' power plants, rolling blackouts are expected to be avoided throughout this summer (Japan Ministry of Economy, Trade and Industry 2011).

The quake severely affected Japan's transportation system. After the quake, all ports in Japan were closed for a short time, and the 15 ports impacted by the disaster were not fully reopened until March 29 (Nihon Keizai Shimbun 2011). Because of the quake, the northeastern part of the Tokaido Shinkansen high-speed rail line was shut down and not reopened to the public until March 24 (The Guardian 2011). Sixty-two of the 70 railway lines run by the East Japan Railway were affected to various degrees, and 23 railway stations and seven lines were completely destroyed (Nihon Keizai Shimbun 2011). The Sendai airport incurred massive losses because it was attacked by the flood caused by the tsunami one hour after the quake. Both Tokyo's Narita and Haneda airports were closed for about 24 hours (The Aviation Herald 2011).

\subsection{Economic Impact}

It is estimated that 23,600 hectares of farmland were ruined and 3-4 percent of the rice production in Japan was affected in this great earthquake and tsunami disaster (Martin 2011). Many large-scale manufacturers of automobiles (for example, Toyota, Nissan, and Honda), steel (for example, Nippon Steel), and chemicals (for example, Mitsubishi Kagagu) were off production (Mainichi Daily News 2011), causing a decline in global automobile production.

The Japan earthquake led to significant fluctuations in the global financial markets. On the day of the earthquake, March 11, the Nikkei Stock Average dropped 5 percent (Reuters 2011), and it dropped another 1000 points (10.6 percent) on March 15, when the seriousness of the nuclear accident became clear (CNBC 2011). Subject to the earthquake, Germany's DAX index and Hong Kong's Hang Seng index also decreased in varying degrees. But the main American stocks experienced a slight increase of 0.5 to 0.7 percent. The world's largest reinsurers, Munich Re and Swiss Re were speculated to suffer total reinsurance losses of 10 billion U.S. dollars (Kucera 2011) even after the losses absorbed by primary insurers and grants from the Japanese government.

The earthquake brought about the rapid appreciation of the Japanese yen, and the yen against the U.S. dollar at one point reached 76.25 yen to 1 U.S. dollar, the highest point since World War II (BBC 2011). Appreciation of the yen is harmful to the Japanese economy, which is heavily dependent on exports.

The Industrial Production Index dramatically decreased by 15.5 percent compared to the index in February (Table 2). Not 
Table 1. Damage from the 2011 Eastern Japan Great Earthquake and Tsunami (as of April 13)

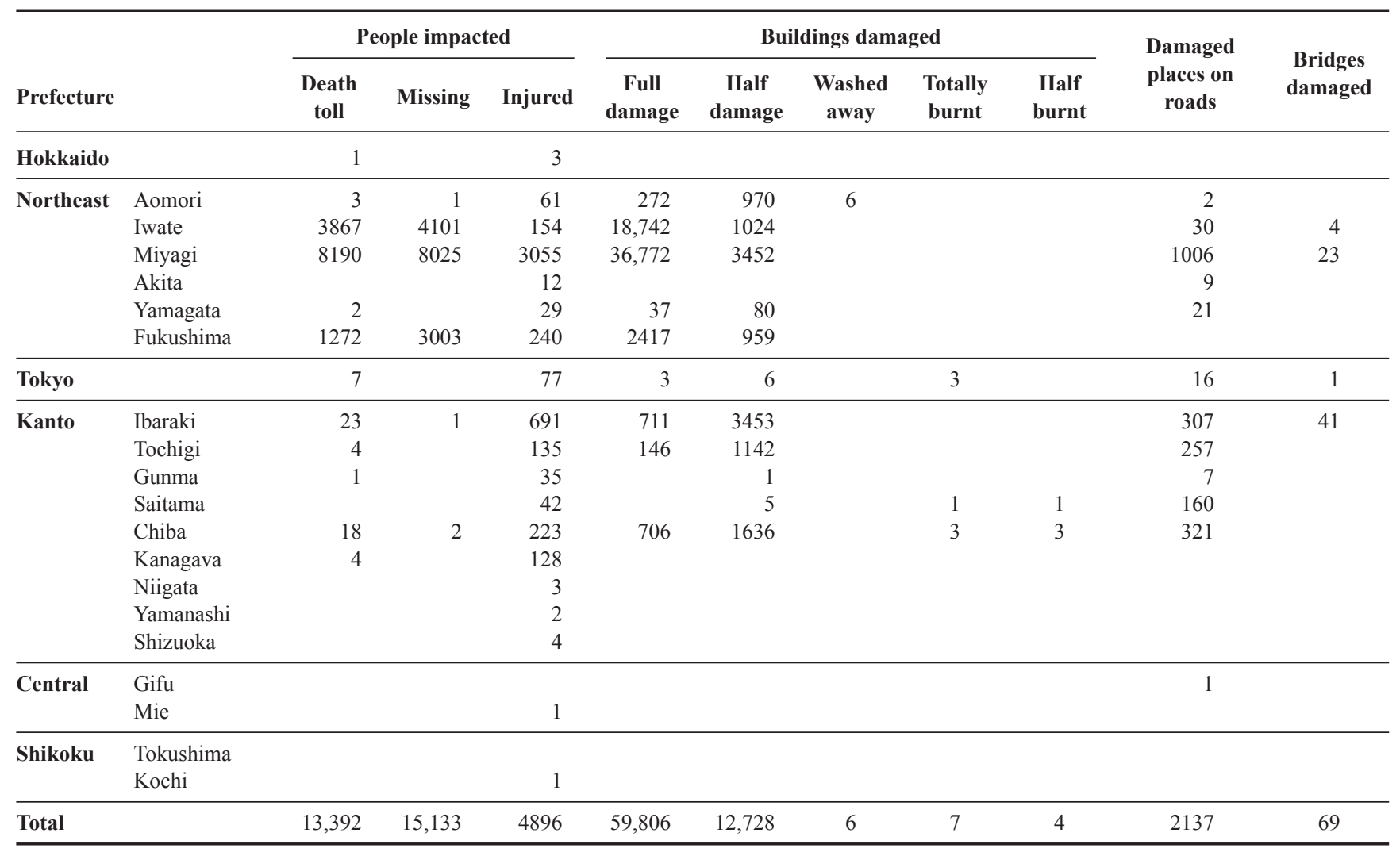

Source: Japan National Police Agency 2011 (excerpt from original table).

only the damaged area, but also the non-damaged areas were suffering from scarcity of materials, and final demand decreases. Because many industries in the upper streams of the supply chains were located in Tohoku, the northeast region of Honshu, and the northeast areas of the Kanto region around greater Tokyo, their damages caused widely spreading economic impacts, which were unforeseen by many crisis managers.

According to an early evaluation by analysts, the earthquake disaster caused direct economic losses of about 171183 billion USD, while the significant cost for recovery might reach 122 billion USD (Pagano 2011). On June 24, the Prime Minister's office crisis management center announced a rough estimation of over 16 trillion yen for property damages alone (Cabinet Office, Government of Japan 2011). This estimation is based on the damage ratio of buildings of the 1995 Hanshin-Awaji earthquake. In the best case scenario (16 trillion yen), the total property damages are 14 trillion yen in three prefectures in the Tohoku region alone. This amounts to about 20 percent of the total economic value of property in these three areas.

\section{The Nuclear Power Plant Crisis}

The earthquake and tsunami created a serious nuclear crisis. Affected by the quake, the 11 nuclear power plants in northeast Japan, including the first and second nuclear power plants in Fukushima, and the nuclear power plants in Onagawa, Genshiryoku, and Hatsudensho, automatically stopped operating their nuclear reactors. However, the cooling system of the first nuclear power plant in Fukushima also stopped working because of the impact of the tsunami, causing the reactor temperature to rise. Although the Japanese government and

Table 2. March 2011 Japan Industrial Production Index (100 in year 2005)

\begin{tabular}{|c|c|c|c|c|}
\hline \multirow{2}{*}{ Item } & \multicolumn{2}{|c|}{ Seasonally Adjusted Index } & \multicolumn{2}{|c|}{ Original Index } \\
\hline & Index & Changes from February (\%) & Index & Changes from February $(\%)$ \\
\hline Production $^{\dagger}$ & 82.7 & -15.5 & 88.7 & -13.1 \\
\hline Shipping* & 85.0 & -14.6 & 95.0 & -12.1 \\
\hline
\end{tabular}

Source: Japan Ministry of Economy, Trade and Industry 2011 (Confirmed version reported on May 19).

t: Weighted average of the amount of major items ( 521 items) produced by the industrial sector. Weight of each item is determined by the added value for each item with respect to the reference year (2005).

‡: Production items shipped from factories, a measurement for actual transaction of goods. 
the operator Tokyo Electric Power Company adopted a series of measures, the nuclear accident gradually became a level 7 nuclear event, which is a major accident and the highest level on the International Nuclear and Radiological Event Scale (INES), equivalent to the Chernobyl disaster in April 1986. The radiation in the vicinity of the reactor rose steeply, becoming a deadly threat to the local residents, as well as polluting vegetables, milk, and water. TEPCO also released tens of thousands of tons of low radiation nuclear pollution water into the Pacific, resulting in grave concern and criticism from neighboring countries.

The way that the nuclear incidents were triggered is plantspecific. However, the most catastrophic consequences have arisen from the Fukushima Daiichi nuclear plant, where three units were exposed to level 7 accidents and one unit was exposed to a level 3 incident. The critical issue in the crisis became the cooling systems failures.

The Fukushima Daiichi nuclear power plant mainly uses reactors to boil water, lets the steam drive steam engines, and returns the cooled water to the reactors to cool them down. In the system, water immerses the fuel rods and cycles in the system with radioactive isotopes. Under normal conditions this is not a problem because the process occurs in a closed cycle. None of the water, steam, and radioactive isotopes can escape from the closed vessel.

The earthquake and subsequent tsunami broke the closed cycle and delivered a deadly strike against the cooling system (Figure 4). The cooling system was designed to be supported with four different power supplies. The offsite power supply from the power grid and the internal power supply from the reactor were down because of the earthquake. The on-site fuel generator started working once the other two power sources failed, but was damaged by the tsunami wave. Emergency back-up batteries appeared to be affected by the tsunami as well, but could at most have lasted for eight hours even if they had been spared from damage. As a result, the cooling system stopped working and this triggered the set of extremely severe consequences.

Due to the nature of the nuclear fuel used in the plant, the core temperature of the reactors dropped only very slowly after the cooling system was down because there was still slow decay even after the reactors had gone off-line. The high temperature turned most of the internal coolant water into steam, which in turn exposed the fuel rods to air. Without the provision of a cooling alternative, the high temperature would have melted down the nuclear fuel rods. Fuel would escape away from control rods, intensify decay, melt through the reactor floor, and consequently induce a massive release of radioactive isotopes, a worst case scenario.

In order to avoid the most catastrophic consequences, operators of the plant tried to inject coolant water from external sources (first seawater, later freshwater). The injected external coolant water, however, was then turned into steam and further increased the vessel pressure, which hampered water injection. As a result, operators had to bleed-off pressure, which resulted in hydrogen explosions and the release of radioactive isotopes from the vessel. Radioactive isotopes released from Fukushima were later detected in North America and other regions in the world. Coolant water that did not escape the vessel in the form of steam accumulated in the bottom of the reactors in highly radioactive form. These waters either leaked or were released by the operator into the Pacific Ocean. Widespread radioactive pollution was created. Worse yet, though countermeasures were adopted, the fuel rods in units 1,2, and 3 of the plant were reported to have experienced major damage and possibly fully melted (TEPCO 2011a, 2011b; CNN 2011). The long-term impact of the nuclear crisis to Japan, the Asia-Pacific region, and the entire world is still not fully revealed.

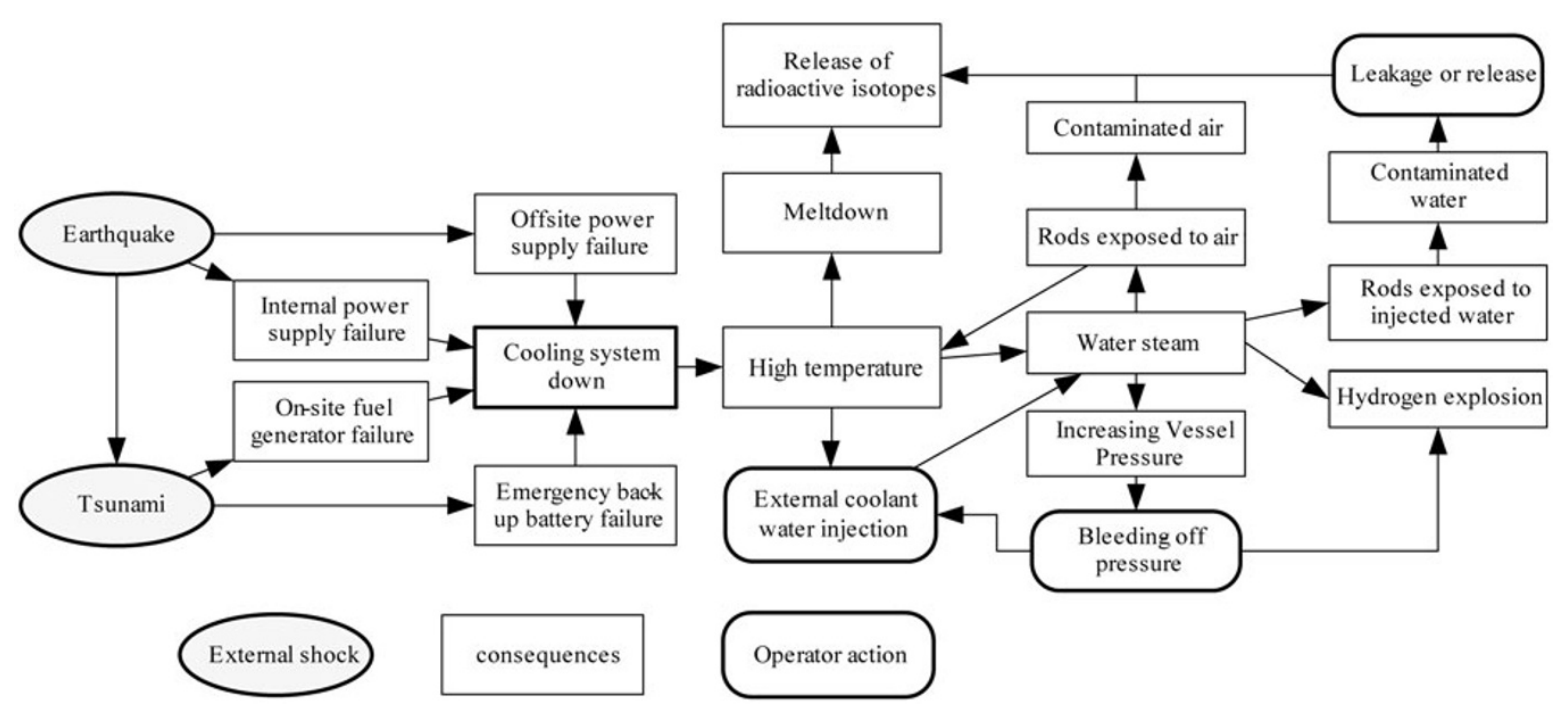

Figure 4. Illustrative chart of the 2011 Fukushima nuclear crisis 


\section{National and International Response}

\subsection{Response of Japan}

After the earthquake, a countermeasure office was immediately set up in the Prime Minister's office crisis management center. The Japanese government established a special headquarters for emergent disasters headed by Prime Minister Naoto Kan. At the press conference on April 13, the Prime Minister declared that it was the most serious disaster in Japan after World War II. The other main response headquarters, also lead by the Prime Minister, was set up for the nuclear crisis. These two headquarters became the main decision-making bodies on crisis management.

The Japanese government also established a government emergency response headquarters headed by Foreign Minister Matsumoto. He said that Tokyo welcomes foreign countries to provide any assistance to Japan, and Japanese government would check foreigners in Japan and confirm security situation of the embassies in Tokyo.

The Japanese government also established a countermeasure headquarters against disasters headed by the Defense Minister, Toshimi Kitazawa. On April 13, the Japanese Prime Minister Naoto Kan asked the Ministry of Defense to send out 100,000 self-defense officers to participate in rescue work. The total number of troops mobilized, including those providing logistics, was 180,000 , the largest number dispatched by the Japan Self-Defense Forces since World War II.

On April 14, the Bank of Japan (the Central Bank) held a monetary policy meeting, discussing the new monetary easing policy to be implemented after the Eastern Japan Great Earthquake Disaster. On March 14, 15, 17, and 22, the Bank of Japan successively injected capital of up to 4 trillion yen in cash into the market (Wearden 2011).

\subsection{International Involvement}

After the quake, Japan specifically requested quake rescue teams from Australia, New Zealand, South Korea, the United
Kingdom, and the United States (Nebehay 2011). It also requested satellite images of available types of the quake and tsunami regions according to the International Charter on Space and Major Disasters.

By March 30, 134 countries and regions and 39 international organizations had expressed their willingness to provide aid to Japan (Figure 5). Twenty-three countries and regions sent out rescue teams and experts on nuclear accidents. The statistical data released by the Narita branch of Tokyo Customs on March 29 showed that, in total, 190 batches and 1300 tons of relief goods from 29 countries and regions arrived at Narita Airport between March 12 and 25. Of these 190 batches, 60 were from China, 40 from the United States, 30 from Thailand, and 20 from Korea. The major types of goods included food, blankets, mineral water, radiation protection suits, and emergency lamps. By April 3 the Japanese Red Cross had received over one billion USD in donations in response to the disaster, and dispatched more than 200 emergency relief teams to the disaster zone.

The earthquake-tsunami induced nuclear crisis has been of grave concern. Many countries started to evacuate their citizens from the northern part of Japan right after the disaster. $\mathrm{UN}$ agencies were widely involved in the nuclear issue, including the World Health Organization (WHO), the International Atomic Energy Agency (IAEA), the World Meteorological Organization (WMO), the International Maritime Organization (IMO), the International Civil Aviation Organization (ICAO), the World Tourism Organization (UNWTO), and the International Labor Organization (ILO). The WHO together with the Food and Agriculture Organization (FAO) conducts inspections and provides information on (sea)food safety after the nuclear accident. The IAEA Briefing on the Fukushima Nuclear Accident is updated on a daily basis since the quake (IAEA 2011). Tourists and other visitors to Japan are advised by the IMO, ICAO, UNWTO, and Japanese government agencies on travel and transport from and to Japan by air or sea.

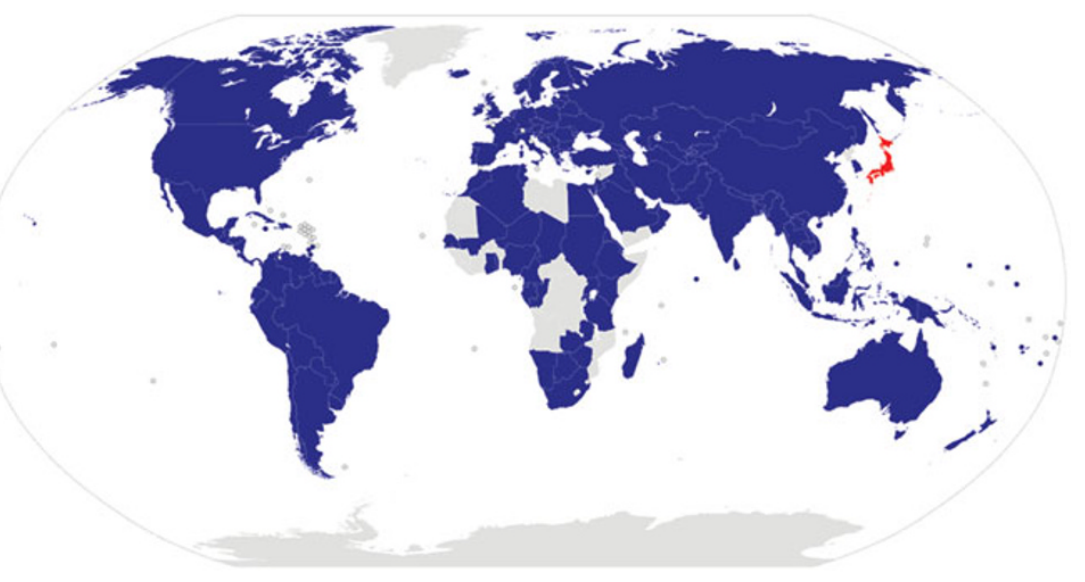

Figure 5. Countries and regions expressed willingness to provide aid to Japan after the 2011 Earthquake disaster Source: Wikipedia 2011. 


\section{Comments and Discussion}

\subsection{Prepared for the Expected}

After the Great Hanshin Earthquake in 1995, the Japanese government and society profoundly reflected on the precautions that needed to be taken against earthquake disasters. Many new measures became the solid foundation for Japan to cope with this most recent earthquake-tsunami catastrophe to some degree.

For example, Japan attaches great importance to scientific research and technological development on disaster prevention and mitigation. The Japan Meteorological Agency operates the world's first earthquake early warning system, which can warn the Japanese people ahead of a quake. It also can detect seismic waves near the epicenter, and send out early warnings through national television and radio networks, even through mobile phones. On the day of the main quake, alarm was sounded around 80 seconds before the beginning of shaking in Tokyo area.

In Japan there are various ways for the public to get access to disaster information - by mass media and cell phone services, for example. The Japanese media have developed a rapid and systematic reporting system for disaster situations, and will promptly disclose all kinds of useful information whenever a natural disaster occurs. Japan also invests heavily in public disaster education, making one of the highest disaster risk aware populations in the world. With the help of disaster preparedness training carried out in communities, the Japanese people have developed the skills and habits of self-relief.

The Self-Defense Troops are granted much power by the government in response to disasters. This is a significant gain from the experience of the Hanshin-Awaji earthquake. In response to the Eastern Japan Great Earthquake Disaster, the Self-Defense Troops played an indispensible role in organizing emergency response actions and accomplished many in-field missions. All of these preparations constituted a solid foundation for the Japanese to raise evacuation rates during the tsunami disaster and reduce the loss of lives.

Japan is also implementing one of the most stringent construction standards in the world, with intensively reinforced residential buildings, bridges, and other infrastructures. It is worth noting that Japan is a leader in earthquake proofing nuclear plants, although a severe nuclear crisis was induced by the earthquake-triggered tsunami. All nuclear reactors automatically stopped operating after the quake. The building damages and the nuclear plant crisis were induced by the tsunami rather than the quake per se.

\subsection{Prepared Beyond the Expected: Where to Go from Here}

The 2011 earthquake-tsunami was so severe that it went far beyond the expectation and coping capacity of Japanese society. The quake was of high magnitude and the energy released was huge. The tsunami triggered by the earthquake critically overwhelmed the coping capacity of the stricken areas. Preparedness is based on expectation and prediction, which had not taken into account the extreme situation that actually unfolded. From that standpoint Japan is not prepared enough.

First, the disaster impact easily overwhelmed local coping capacity. Although local evacuation centers and public buildings were available for the local people, there were cases in which many old people died because they were not able to evacuate quickly. In the field survey conducted by the authors, some concrete buildings stood after the tsunami disaster, which potentially could have become emergent evacuation shelters if they had been reinforced/upgraded. Although disaster evacuation drills were held regularly in many local communities, they were not helpful to all segments of the population because the evacuation centers were not easily accessible for many old people and it was difficult for them to be really involved in these drills. Emergency evacuation plans and drills require further improvement.

Second, Japan is not prepared for a truly "mega" disaster. Experiences in other countries have shown that a large-scale disaster cannot be coped with solely by local capacities and aid from outside of the stricken region is indispensible. In this earthquake disaster, the damaged/affected areas were so extensive that clusters of local governments for cities and prefectures were paralyzed. Not only the public sectors, but also many private sectors were unable to provide adequate services during this disaster due to damaged infrastructures. These services include providing energy, food and water, and medical treatment. A typical example of these difficulties is the power frequency difference between East Japan and West Japan. In Kansai area the frequency of electricity is $60 \mathrm{~Hz}$, while in Kanton area it is $50 \mathrm{~Hz}$. Though there are two stations able to covert frequency, the capacity is limited to $1 \mathrm{GW}$, far below the drop due to power plant failure.

Third, Japan's response system is not as efficient as it could be. A valuable lesson drawn from the Chinese experience in dealing with the Wenchuan Earthquake in 2008 (Shi et al. 2009) is the significance of centralized power in coping with large-scale disasters. In this earthquake-tsunami disaster, the Japanese government appeared not as powerful as had been expected in resolving many issues, particularly with respect to the nuclear crisis. Coordination between the government (emergency response headquarters), the Tokyo Electric Power Company, and the nuclear and industrial safety agency were not sufficiently organized. Information was not simultaneously shared right after the disaster, which delayed efficient decision making.

Finally, Japan, as well as probably all nuclear countries in the world, is not truly prepared for nuclear crises. Although there were two types of back-up power supply available in the Fukushima nuclear power plant, they simply failed because they were as vulnerable as the major power supply systems. "Backup" did not make sense in this case. Obviously, a major tsunami was not in the plan of the designer and operator of the 
plant. This is a serious mistake because these plants are located exactly in the coastal and earthquake-prone region of the country.

\subsection{Prepared for Unexpected Large-Scale Disasters}

Several issues regarding the governance of large-scale disaster risk arise from the experience of the Eastern Japan Great Earthquake Disaster.

(1) The severity and unexpectedness of large-scale disasters require a global, synergic, and efficient response system. The response needs to mobilize all available resources, from public and private sectors, affected and unaffected areas, domestic and abroad. The response needs to highly coordinate all disaster response entities so that the synergic effect is achieved. The response must be founded on rational strategies with orderly and efficient arrangements based on the emergency plans. In this sense, centralized power in the face of large-scale disasters is indispensible.

(2) The regionalized and globalized impacts of large-scale disasters call for a new international platform to cope jointly. The recent experiences of catastrophes worldwide imply that the impact of a catastrophe is no longer confined to the affected areas but spreads around the world in the context of globalization. The mismanagement of the affected countries will bring about serious consequences for the surrounding countries or even the whole world.

The radioactive contamination caused by the nuclear accident following the earthquake and tsunami is affecting the rest of the world through atmospheric circulation. The polluted water released by the Tokyo Electric Power Company is likely to affect the entire Pacific Ocean in the coming decades. In the long term, impacts of radiation should be carefully monitored and assessed based on data derived from previous nuclear accidents and state-of-the-art medical knowledge. International frameworks are required to do so.

The Japanese economic instability caused by the quake affects the yen and Japan's domestic economy, which draws attention from the G7 (Group of Seven) that is already planning to intervene against the yen when necessary. Moreover, the existing international framework of humanitarian aid cannot meet the demand of coping with large-scale disasters. A mutual assistance system that incorporates a higher degree of international involvement in coping with large-scale disasters should be established.

(3) The complexity of the catastrophic impact urges us to conduct further studies on multi-hazard and disaster-chain issues. Due to the super-energy released in the catastrophe, many regional physical-geographical factors are likely to cross critical thresholds of balance and create secondary hazards, which will transmit and enlarge the disaster in the form of disaster chains to an extent beyond regional endurance. In the 2008 Wenchuan Earthquake in China, for example, the quake generated a huge amount of loose soil and rocks, inducing landslides and debris flow. In the Eastern
Japan Great Earthquake Disaster, what mattered most was not the quake but the tsunami as well as the nuclear crisis that it triggered. The chained-triggering phenomenon is similar to other catastrophes in recent years. It is also a critical reason that large-scale disasters generally claimed huge losses. Therefore, it is necessary to study the formation mechanism of disaster chains and issue region-specific precautions against potential disaster chains.

(4) Key infrastructures require more robust systems planning and design. Here key infrastructures refer to those that can largely facilitate disaster relief efforts, for example, life-line projects and transportation hubs, or those that create serious threats, such as nuclear power plants and major water dams. Failure of a key infrastructure would lead to the failure of an entire system. In most cases problems only need to occur in one or several small but critical components. The power supply for the cooling system is only a subsystem of the Fukushima power plant, but its failure collapsed the entire system and was fatal. Event tree analysis, network analysis, and systems engineering will be necessary for understanding this issue.

\section{Note}

i NHK, March 17, 04:01 am. Evacuees by prefecture: Miyagi- 205,418, Fukushima- 64,040, Iwate- 44,433, Yamagata- 2217, Aomori- 371, Akita- 40, Ibaraki- 12,347, Chiba- 1010, Tochigi- 1696, Gunma- 63, Saitama- 107, Niigata- 3200, Nagano- 1579.

\section{References}

The Aviation Herald. 2011. Tsunami Rolls through Pacific, Sendai Airport under Water, Tokyo Narita Closed, Pacific Region Airports Endangered. March 11. http://avherald.com/h?article=43928907\&opt $=0$.

BBC (British Broadcasting Corporation). 2011. Yen Hits Record-High against US Dollar as Nikkei Falls. March 17. http://www.bbc.co.uk/news/ business-12768098.

Cabinet Office, Government of Japan. 2011. On the Estimation of Loss of the Great Eastern Japan Earthquake (東日本大震災における被害額の推 計について). http://www.bousai.go.jp/oshirase/h23/110624-1kisya.pdf.

CBS News. 2011. Earth's Day Length Shortened by Japan Earthquake. March 13. http://www.cbsnews.com/stories/2011/03/13/scitech/main2004 2590.shtml.

Chai, C. 2011. Japan's Quake Shifts Earth's Axis by 25 Centimetres. Montreal Gazette (Postmedia News), March 11. http://www.webcitation. org $/ 5 \times 95$ t0CLU.

Chang, K. 2011. Quake Moves Japan Closer to U.S. and Alters Earth's Spin. The New York Times, March 13. http://www.nytimes.com/2011/03/14/ world/asia/14seismic.html.

CNBC. 2011. Treasuries-Surge Following Nikkei Plunge. March 15. http:// www.cnbc.com/id/42085204.

CNN (Cable News Network). 2011. Nuclear Reactors Melted down after Quake, Japan Confirms. June 6. http://www.cnn.com/2011/WORLD/ asiapcf/06/06/japan.nuclear.meltdown/index.html?hpt=hp_t2.

Earthquake Survey Committee, Japan. 2011. Long-Term Evaluation of Earthquake Origins from Sanriku-Oki to Bousou-Oki. http://www.jishin. go.jp/main/chousa/11mar_sanriku-oki/p09.htm. 
The Guardian. 2011. Japan Disaster: Reconstruction Effort Puts Town on Road to Recovery. March 24. http://www.guardian.co.uk/world/2011/ mar/24/japan-disaster-reconstruction-road-recovery.

IAEA (International Atomic Energy Agency). 2011. Fukushima Nuclear Accident Update Log. http://www.iaea.org/newscenter/news/tsunamiup date $01 . \mathrm{html}$.

Japan Meteorological Agency. 2011. The 2011 off the Pacific Coast of Tohoku Earthquake Distribution of JMA Seismic Intensity. http://www. jma.go.jp/jma/en/2011_Earthquake/2011_Earthquake_Intensity.pdf.

Japan Ministry of Economy, Trade and Industry. 2011. Economic Impact of the Great East Japan Earthquake and Current Status of Recovery. May 17. http://www.meti.go.jp/english/earthquake/recovery/index.html.

Japan National Police Agency. 2011. Damage and Police Responses to the Northeast Pacific Earthquake [平成23年(2011年)東北地方太平洋沖 地震の被害状沉と警察措置]. April 13. http://www.npa.go.jp/archive/ keibi/biki/index.htm.

Japan Times. 2011. Utilities' Monopoly on Power Backfires. March 30. http://search.japantimes.co.jp/cgi-bin/nn20110330a4.html.

JMRI (Japan Meteorological Research Institute). 2011. Estimation of the Tsunami Wave Source Zone of the 2011 Eastern Japan Great Earthquake [平成23年(2011年)東北地方太平洋沖地震の津波波源域の推定] http://www.mri-jma.go.jp/Topics/press/20110324/press20110324.pdf.

Kucera, D. 2011. Reinsurers Decline as Japan Quake, Tsunami May Cause $\$ 10$ Billion in Claims. Bloomberg, March 11. http://www.bloomberg. com/news/2011-03-11/european-reinsurers-fall-leading-u-s-carrierslower-on-quake.html.

Kyodo News. 2011. 38-Meter-High Tsunami Triggered by March 11 Quake: Survey. April 3. http://english.kyodonews.jp/news/2011/04/82888.html.

Martin, A. 2011. Farmers Struggle amid Tsunami aftermath. Japan Times, April 8, 3 .

Mainichi Daily News (Tokyo). 2011. Toyota, other Automakers to Suspend Production at all Domestic Plants. March 13. http://www.webcitation. org/5x9RsDbNC.

Nebehay, S. 2011. Japan Requests Foreign Rescue Teams, UN Says. Reuters. http://www.reuters.com/article/2011/03/11/us-japan-quake-aid-refile-id USTRE72A71320110311.

NHK World (Nippon Hōsō Kyōkai - Japan Broadcasting Corporation). 2011. 190,000 Buildings Damaged by March 11 Quake. April 3. http://www. japan.org/archives/1304.

Nihon Keizai Shimbun (Japan Economic Times). 2011. 90 Percent of Major Transport Networks back in Operation. March 29. http://e.nikkei.com/e/ fr/tnks/Nni20110328D28JFF01.htm.
The Nikkei. 2011. Power Outage to Deal Further Blows to Industrial Output. March 14. http://e.nikkei.com/e/fr/tnks/Nni20110313D13JFF08.htm.

NOAA (National Oceanic and Atmospheric Administration). 2011. Japan Tsunami Wave Heights. http://sos.noaa.gov/datasets/Ocean/japan_quake_ tsunami.html.

Pagano, M. 2011. Japan Looks for Market Stability after Quake. The Independent, March 13. http://www.independent.co.uk/news/business/news/ japan-looks-for-market-stability-after-quake-2240323.html.

Port and Airport Research Institute. 2011. The Situation of Damage of Ports in Tohoku Region (Site Survey) (2011 Tōhoku Earthquake and Tsunami) [東北地方の港湾における被災状沉にっいて(現地調査速報)]. March 23. http://www.pari.go.jp/information/20110311/p20110323.html (in Japanese).

Reuters. 2011. Japan Earthquake: Market Reaction. March 11. http://www. telegraph.co.uk/finance/markets/8375674/Japan-earthquake-marketreaction.html.

Shi, P. J., L. Y. Liu, J. A. Wang, W. Xu, W. H. Fang, and M. Wang. 2009. Experiences and Lessons of Large-Scale Disaster Governance in China: Perspective to the Response of Wenchuan Earthquake Disaster. Paper presented at the International Human Dimensions Program (IHDP) 2009 Open Meeting, 26-30 April 2009, Bonn, Germany.

TEPCO (Tokyo Electric Power Company). 2011a. Reactor Core Status of Fukushima Daiichi Nuclear Power Station Unit 1. May 15. http://www. tepco.co.jp/en/press/corp-com/release/betu11_e/images/110515e10.pdf.

- 2011b. Status of Cores at Units 2 and 3 in Fukushima Daiichi Nuclear Power Station. May 23. http://www.tepco.co.jp/en/press/corp-com/release/ betu11_e/images/110524e14.pdf.

USGS (U.S. Geological Survey) Earthquake Hazards Program. 2011a. USGS Energy and Broadband Solution near east coast of Honshu, Japan. $\mathrm{http}: / /$ earthquake.usgs.gov/earthquakes/eqinthenews/2011/usc0001xgp/ neic_c0001xgp_e.php.

_. 2011b. USGS WPhase Moment Solution Near East Coast of Honshu, Japan. http://earthquake.usgs.gov/earthquakes/eqinthenews/2011/usc0001xgp/ neic_c0001xgp_wmt.php.

Wearden, G. 2011. Bank of Japan Pumps Billions into Financial Markets. The Guardian, March 14. http://www.webcitation.org/5xDFjXIOU.

Wikipedia. 2011. File: Map of Humanitarian Support to the Great Eastern Japan Earthquake.svg. http://en.wikipedia.org/wiki/File:Map_of_ humanitarian_support_to_the_Great_Eastern_Japan_Earthquake.svg.

Xinhuanet. 2011. Flood Risks Increase in Japan's Quake Areas. http://news. xinhuanet.com/english2010/world/2011-03/18/c_13786573.htm.

Open Access This article is distributed under the terms of the Creative Commons Attribution License which permits any use, distribution, and reproduction in any medium, provided the original author(s) and source are credited. 